Editorial

\title{
Public sector governance and accountability
}

\section{Introduction}

The collection of papers in this special issue has primarily been drawn from the papers representing the "Corporate Governance and accountability in the Public Sector" stream of the Seventh International Critical Management Studies Conference (CMS 7), which was held at the University of Naples Federico II, Italy, in July 2011. The stream was inspired by international reforms focussed on the modernization of governments. These reforms have been implemented at central, regional and local levels, and are based on the assumption that improving the mechanisms of governance and accountability will enhance the performance results in the public sector (Aucoin, 1990; Pollitt and Bouckaert, 2011). A wide range of actors have been involved in the public sector reforms, such as corporations, foundations, and other agencies including both private and intergovernmental actors. They have all played a role in defining the requirements for new governance and accountability mechanisms (Christensen and Laegreid, 2007). In this respect, the focus has particularly been on how governance and accountability have become diffused in the public sector context and how the multiple actors interact in this new arena (Dubnick, 2005; Humphrey et al., 1993; Mulgan, 2000).

The remainder of this editorial is structured as follows. Section 2 introduces some views on governance and accountability in connection with the public sector reforms. Section 3 gives a synopsis of the contributions to this special issue from the perspective of the broader domain of public sector governance and accountability. Finally, Section 4 reflects on the papers and offers some perspectives for future research.

\section{Views on public sector governance and accountability}

In order to understand the changing roles of governance and accountability as part of the recent public sector reforms, we will firstly introduce some general notions regarding public sector governance and accountability. Subsequently, we will introduce the concepts of New Public Management (NPM) and New Public Governance (NPG) as recent reform packages, and show the role of governance and accountability therein.

\subsection{Governance and accountability}

"Governance" has become one of the buzz-words in modern social sciences. In the most general sense governance deals with the steering and coordination of various actors, often in network-type patterns of collaboration (see classical works on governance, e.g. Rhodes, 1997 or Kooiman, 2003). Although there are also cases of "governance without government", usually a governance structure contains at least one governmental institution. Governance is an umbrella term which includes different meanings and perceptions and is widely used in political sciences as well as in economics and management. Although governance also covers hierarchical forms of steering ("government"), it is usually associated with other governance modes, primarily markets or networks (Bevir, 2009).

To indicate control issues in the context of corporations the term "corporate governance" was established. Corporate governance can be defined as a concept of structures, rules, procedures and mechanisms for the proper steering and controlling of corporations (Colley et al., 2005; OECD, 2004). In the private sector corporate governance is the umbrella term for all aspects of the powers and competences in the relations among different organizational units and between the organization and its various stakeholders (particularly: shareholders). In the frequent case of separation between ownership and management, the corporate governance concept ensures the influence of the owners of the business on its management. Most aspects of the corporate governance of companies are regulated in company law; usually according to the legal status of the firm. Other aspects are covered by soft law, e.g. corporate governance codes. 
Public sector governance concerns accountability tasks in relation to the specific goals of this sector, which are not limited to service delivery (e.g. cost and quality of services) but also include the impact of the policies on the community or the society at large (e.g. policy outcomes or value for tax money). Governance includes various types of mechanisms, particularly structures that clarify the responsibilities of the various stakeholders as regards the organization, approaches that foster the capabilities for meeting these responsibilities, and tools such as systems for internal control and external accountability. In his historical review of the governance concept, Goddard (2005, p. 195) distinguishes at least three dimensions of governance: conformance, performance and structure. The above indicated governance mechanisms can also be observed in the codes of conduct for good governance in the public sector (compare, for example: The Independent Commission on Good Governance in Public Services, 2004). If we want to understand accountability mechanisms, we have to consider them in the context of governance as indicated here. Accountability can have different meanings. Basically, it refers to the giving and demanding for good conduct, but some authors (Smyth, 2012, pp. 231-232) are more strict in the sense that they emphasize the need for control (sanction and reward) as an instrument to formalize the concept, because otherwise it would be merely associated with answerability and transparency.

Bovens provides a rather concise definition of accountability: "A social relationship in which an actor feels an obligation to explain and to justify his or her conduct to some significant other” (2009, p. 184). The accountability concept is primarily associated with power delegation from shareholders (principal) to managers (agents) and the way to ensure the relationship between the agents and the principals (Broadbent et al., 1996; Gray and Jenkins, 1993; Sinclair, 1995). In order to define who the principal is and who the agent is, the questions of who is responsible to whom and for what needs to be answered (Bovens, 2009). This issue has resulted in the discussion of accountability towards stakeholders outside the organization as well as among the different levels of the organization, i.e. external and internal relations (Deleon, 1998; Romzek and Dubnick, 1987). Thus, a distinction can be made between internal and external accountability (Grossi and Thomasson, 2011). Accountability is context-specific. It has to be adjusted to both the type of organization and the object for which the organization is accountable (Roberts and Scapens, 1985; Romzek and Dubnick, 1987).

\subsection{Further thoughts on public sector accountability}

Public sector accountability traditionally concerns the relationship between politicians and citizens, as well as to that between politicians and public managers (Barberis, 1998; Mulgan, 2000). Bovens notes that the concept of public sector accountability has become "a rhetorical device serving as a synonym for many loosely defined political desiderata, such as transparency, equity, democracy, efficiency and integrity" (2009, p. 183). Since the concept has recently been expanded it can now also be applied to more complex relationships. Greiling and Spraul (2010) point out that the provision of information within the accountability relationship can be supply or demand-driven. Accountability is not limited to a principal-agent relationship, and vice versa, actors can be accountable to a number of parties inside and outside their organizations. To this end, different types of accountability have been identified depending on the type of relationship concerned, which means that it can now involve a broader spectrum of stakeholders (André, 2010; Barberis, 1998; Sinclair, 1995). Given the heterogeneity and complexity of the interests at stake in the public sector, public organizations may tend to opt for ambiguous strategies and goals which are less likely to be rejected by the electorate than clear-cut policies, and will allow the politicians to maintain or increase their political consensus.

Public sector accountability has several forms: authors distinguish between internal and external (Romzek, 2000; Romzek and Dubnick, 1987); direct and indirect (Polidano, 1998); and vertical and horizontal accountability (Barberis, 1998; Bovens, 2009; Mulgan, 2000; Hodges, 2012). Accountability in the public sector is described as a heterogeneous, complex chameleon-like and multifaced concept encompassing several dimensions (Barberis, 1998; Mulgan, 2000; Sinclair, 1995). According to Shaoul et al. (2102, p. 221), the public sector context with its multiple stakeholders requires a multidimensional external reporting instrument which covers multiple areas, such as the use and stewardship of resources, the cost and quality of services, financial probity and financial control over public resources. Sinclair (1995) even defines a much broader set of accountability forms for the public sector, which goes beyond the scope of financial dimensions, by also including political (or democratic), public, managerial, bureaucratic, professional, and personal accountability. Moreover, this author sees accountability as multiple and fragmented: "being accountable in one form often requires compromises of other sorts of accountability" and moreover she suggests that "accountability is continually being constructed" (Sinclair, 1995, p. 231).

The public sector accountability dimension becomes even more interesting and significant when considering the "big paradigm shifts" that have taken place over the years in public management and accounting. In the next section we will focus on the current shift in public management and accountability as discussed by the recent research literature on this topic, namely that from New Public Management to New Public Governance.

\subsection{From New Public Management (NPM) to New Public Governance (NPG)}

During the past three decades the management of public sector organizations has been subject to major changes. The umbrella term used to characterize these changes is New Public Management (NPM). In general NPM has been a response to accusations directed at the public sector of being bureaucratic, inefficient and ineffective. As a neoliberal doctrine NPM supports, among other goals, the integration of private sector management concepts and market mechanisms into the public 
sector (Reichard, 2010). Hood (1995) claims that changes in public sector accounting have been central in the rise of NPM. He further suggests that the development of NPM has been the result of a broader shift in views regarding public accountability and public administration.

In comparison with the traditional concepts of public administration, NPM has been based on a different conception of public accountability, entailing a different approach to trust and distrust in social and economic transactions resulting in a different style of "accountingization" (Power and Laughlin, 1992) and political language (Watkins and Arrington, 2007). Also previous studies have suggested that this new language, for example in terms of performance information, was first of all used in external accountability relationships, rather than in the internal management communication. In this new conception of accountability accounting was the key element, reflecting a high trust in the market and private business methods and a low confidence in the public servants and the traditional professionals, whose activities had to be closely evaluated through sophisticated accounting and management techniques. There was an increasing tendency towards the adoption of private-sector managerial and accounting techniques in order "to make the public sector more business-like" (Lapsley, 1999; Olson et al., 1998). However, the private sector methods, practices and accounting tools were mostly adopted without a thorough analysis of the public sector's specific objectives and characteristics.

New Public Governance (NPG) has its origins in the radical changes introduced in the public policy in the 1980s and 1990s, and can be partly regarded as a response to the NPM-oriented developments in the public sector, especially with respect to 'marketization' and 'accountingization' (Osborne, 2010). According to Antiroikko et al., NPG refers to the "steering, coordination and use of the institutional arrangements formulated in policy-making and implementation processes aimed at the collective interest in a polycentric multi-sectoral stakeholder context to pursue the collective interest" (2011, p. 3). So, NPG contrasts with NPM in at least two respects: (1) NPG is primarily focussed on public sector values (as opposed to private sector values) and (2) NPG starts from the perspective of networks of organizations (as opposed to that of individual organizations and their relations with clients). The term "governance networks" is used to label the more or less stable patterns of societal relationships (interactions, cognitions, and rules) between mutually dependent (public, semi-public, and/or private) actors in complex policy issues or policy programmes (Koppenjan and Klijn, 2004, pp. 69-70).

In these relationships public sector organizations are confronted with some strategic choices. Three strategic choices can be distinguished with regard to public sector reforms such as NPM or NPG:

\section{- Defining the organizational boundaries.}

- The structure of the contractual relationships and the development of resource management.

- The organization's internal control and communication systems, i.e. the organizational structures.

Regarding the first choice, NPM has promoted the outsourcing of both core, often standardized, services (e.g., issuing of permits, education) and non-core services, such as support tasks (e.g., IT, financial administration). However, research has shown that this approach can lead to an increase in the transaction costs, because public service providers tend to behave opportunistically to serve their own interests (Hoffman et al., 2010; LeGrand, 1999). Competition among providers with the same goals and distrust between these providers and the purchasers often lead to higher transaction costs and an ineffective use of common resources (Barretta, 2008). Moreover, other studies have pointed to the poor evidence of benefits other than costs decrease (Almqvist, 2004; LeGrand, 1999) and reported that providers are more focussed on quantity than on quality (Lapsley, 2009). Partly as a response to these findings, policy changes were enacted in favour of cooperation, involving organizational boundary-spanning efforts for sharing knowledge and even resources (Kurunmäki and Miller, 2011) to enhance networking and collaboration among organizational entities. According to NPG, the make-or-buy decision formerly associated with the NPM paradigm has become a means by which resources, knowledge, and different competencies are shared to promote cooperation in the provision of services. This development has called for new ideas about how these resources should be used and shared and how new accountability relationships between actors should be managed.

Regarding the second choice, the NPM view on contractual relationships is considerably influenced by the traditional neoclassical perspective on contracts. According to Walsh et al. (1997), in this view the contract is an impersonal process in which the parties involved come to an agreement about their formal commitments to each other. They are held to these commitments and should they fail to respect them, sanctions will follow. The law stands behind these agreements as an instrument for resolving possible conflicts. In this traditional view, the contract carefully allocates the risks, responsibilities and rewards between the contract parties. The relationship between the client and the contractor is limited to matters specifically concerned with the exchange of the services or goods. The contract strictly and comprehensively defines its terms and limits. This view on contracts is based on the notion of conflicting interests between the client and the contractor, whereby the contractor will not act in the interest of the client without the threat of sanctions. In a similar vein, the client will exploit the contractor, if possible. If the contractor fails to deliver, he will be punished (e.g., through delays or reduced payments).

However, a quite different perspective on contracts and accountability is the one based on the idea that in entering into a contract, the purchaser and the provider have agreed to a close cooperation (Walsh, 1995). This view has been dominant in the recent NPG debate (Osborne, 2006). The cooperative contract starts from the assumption that there has to be a certain degree of trust between the client and the contractor, and that punishment is not an appropriate means of dealing with failure. It is argued that in case of insufficient performance delivery the best response to failure for both the client and the contractor is to be willing to cooperate in solving the problem. In situations where the service provision is so complex that 
ultimate control is difficult and contracts are insufficient, the parties involved may opt for a system of 'relational contracting'. In this context the emphasis shifts from a detailed specification of the contract components to a number of more general statements which can be adjusted over time (Ferlie et al., 1996; Walsh et al., 1997; Watt, 1998).

NPG-type relationships built on networks of different competencies, emphasizing common interests and blurring the purchaser/provider split, have seemed to receive increasing support these days. However, at the same time, there is still a large focus on the logic underlying the market mechanism and competition principles, which makes the current situation multifaceted in the sense that many of the NPM-based management styles remain to be widely used (Lapsley, 2009). In today's harsh financial climate the introduction of new innovative ways of managing public organizations are difficult to legitimize and maintain (Almqvist et al., 2011). Hence, not only have the organizational boundaries and the accountability relationships changed, also the third strategic issue, organizations' internal management and control, has altered over the years.

With respect to this last issue, the overall trend - as indicated above - regarding the management control during the last decades has been a call by both researchers and practitioners for broadening the management routines beyond the traditional financial control of organizations. This development has promoted a technology-driven trend towards increasing the diversity of performance indicators, aimed at extending the amount of controllable aspects within organizations. However, also this trend has been criticized. Some claim that it may lead to a disproportionate focus on measurability at the expense of the sustainable provision of public value. Power and Laughlin (1992) call this development "accountingization", Power (1997) describes it as the rise of the audit society, while Lapsley (2009) labels it the "tick box mentality". Moreover, the ambition to measure an increasing amount of controllable aspects has created a paradox in terms of the quality logics, in the sense that what is difficult to measure (especially the outcome) has a tendency to be ignored (Almqvist, 2001).

More recent reforms, however, include a wider range of parties (such as corporations, foundations, and agencies employing both private and intergovernmental actors), which has increased the need for new governance and accountability mechanisms related to the specific characteristics of public networks. "The effect has been to deprive particularly the political but also administrative leadership of levers of control and of influence and information, raising question of accountability and capacity" (Christensen and Laegreid, 2007, p. 12). Organizational interdependence has become an ubiquitous concept and the steering of complex sets of interdependent organizations is becoming increasingly difficult for governments. Rhodes predicted that "hollow state erodes accountability" and "institutional complexity obscures who is accountable to whom and for what" (Rhodes, 1997, p. 147). Moreover Bovens' (2009, p. 201) points out that "the most important consequence is a decrease in intensity and scope of public accountability". Others have argued that these reforms are not so much a threat to accountability in the public sector, but do require new solutions (Deleon, 1998).

\subsection{NPM and NPG implications for performance measurement and accountability}

Klijn (2012) makes a clear distinction between NPM and NPG. NPM is more hierarchical and typically based on contractual relationships, whereas NPG recognizes the importance of interdependent horizontal relationships. The latter does not mean, however, that governance networks are completely horizontal. As Klijn (2012, p. 207) indicates: “In governance networks there are also vertical elements because actors have different resources and these cause inequalities in the relations through asymmetrical resource dependencies, while formal contracts between various layers of government levels, for instance, create some vertical relationships".

Hodges (2012, p. 30) made a distinction between vertical and horizontal accountability. Vertical accountability refers to "the legal structures underlying public sector organisations and which conform to the processes of authorisation and defined mandates. It is linked to liberal political theory in which bureaucrats deliver outputs while politicians should be responsible for outcomes". Horizontal accountability concerns the moral and social obligations as perceived by organizations to report to stakeholders or the mutual arrangement between bodies of equal standing to provide public services (Bovens, 2007).

Since the 1980s the public sector's boundaries as well as its financing and management methods, governance structures, responsibilities, controls and accounting concepts have significantly changed (Chan, 2003; Guthrie, 1998; Lüder and Jones, 2003). The accounting systems have been adapted to the changing demands of public governance, which has clearly influenced these systems' use and content (Broadbent and Guthrie, 2008). The growing need for both financial and political accountability demands a broader and more complete set of management and accounting systems to provide feedback for decision-making and for improving accountability (Broadbent et al., 1996; Chan, 2003; Chow et al., 2007; Humphrey et al., 1993).

Table 1 summarizes our discussion of the changing focus of accountability under NPM and NPG.

As indicated above, NPM is primarily based on a vertical and hierarchical view, whereas NPG emphasizes a horizontal focus. In addition, the approaches differ in terms of their scope, i.e., NPM is particularly concentrated on the outputs of individual organizations (result-orientation) while NPG is aimed at results, especially the outcomes of collaborative efforts. The difference between NPM and NPG is in fact threefold: the types of performance indicators differ, the design of the performance information systems differs, and the use of these systems differ (Van Helden et al., 2012). NPM represents a 'command and control' manner of using performance information, while the function of performance information within networks is mainly to support processes of debate and dialogue among the partners with different competencies, who are dependent on each other but not in a hierarchical sense. This context promotes clear and accessible performance information (Ahrens and Chapman, 2004; de Bruijn and van Helden, 2006; Wouters, 2009). Behn (2003) argues that different objectives 
Table 1

A comparison of public sector accountability between NPM and NPG.

\begin{tabular}{|c|c|c|}
\hline & New Public Management (NPM) & New Public Governance (NPG) \\
\hline Focus & Intra-organizational focus & Inter-organizational focus \\
\hline Objectives & $\begin{array}{l}\text { Improving the efficiency and effectiveness of the } \\
\text { single organizations' public service delivery }\end{array}$ & $\begin{array}{l}\text { Improving the inter-organizational coordination and } \\
\text { outcomes of a network of organizations with different } \\
\text { competencies }\end{array}$ \\
\hline \multirow[t]{2}{*}{ Accountability dimensions } & Vertical performance of single organizations & Horizontal performance of the network of organizations \\
\hline & Accountability in terms of results (outputs) & Accountability in terms of the outcome of the network \\
\hline \multirow[t]{2}{*}{ Management control } & $\begin{array}{l}\text { Hierarchical control of the results of single } \\
\text { organizations through performance indicators on } \\
\text { efficiency and effectiveness }\end{array}$ & $\begin{array}{l}\text { Enabling control through dialogue-driven systems of } \\
\text { performance indicators, strengthening the contribution } \\
\text { of individual organizations to the network performance }\end{array}$ \\
\hline & Managing the outputs by assessing the objectives & $\begin{array}{l}\text { Governing the outcome by analysis/evaluation of the } \\
\text { network }\end{array}$ \\
\hline Accounting & Financial reporting of single public organizations & $\begin{array}{l}\text { Whole-of-Government Accounting and consolidated } \\
\text { reporting }\end{array}$ \\
\hline
\end{tabular}

Source: Adapted version of Klijn's model (2012: p. 209).

require different types of performance indicators. This view could imply that performance information for accountability purposes differs to some extent from performance information for control purposes. Two aspects may stand out. First, the information in accountability reports is generally more comprehensive than that in control reports, which are particularly focussed on the specific tasks and responsibilities of the managers. Second, in control reports the performance indicators selected are related to the concept of controllability, while accountability reports also contain information on elements which are particularly relevant to external stakeholders but outside the scope of the managers and politicians in question.

Differences also exist in terms of accounting and financial reporting. While NPM is linked to individual organizations using comprehensive concepts of financial reporting (accrual accounting), NPG has a multi-organizational focus with a particular interest in "Whole-of-Government Accounting" (WGA) and consolidation issues (Grossi and Newberry, 2009). The consolidated report in the public sector provides an overview of the financial performance and position not only of the single organization but of the whole group of organizations which are under its control and provide public services (Broadbent et al., 1996; Chan, 2003; Chow et al., 2007).

\section{Summary of the papers in this special issue}

This section summarizes the six papers in this special issue. Apart from describing the papers' research aim and main findings, we will also try to position the papers in the broader domain of the theme of this special issue: public sector governance and accountability. The first three publications discuss issues of performance measurement for accountability purposes from distinct viewpoints and theoretical perspectives. The fourth paper critically points out the non-neutrality of accountability relationships, and the final two papers deal with more specific issues of public sector governance, particularly the way in which internal auditors cope with role conflicts and the financial expertise of oversight body members in a public sector context.

\subsection{Changing governance and accountability through performance measurement}

The need for a larger extent of accountability mostly goes hand in hand with more autonomy. The paper by Michael Habersam, Martin Piber and Matti Skoog studies this phenomenon in the context of reforms in the Austrian university sector. Before 2002 the universities in this country were hierarchically linked to the Ministry of Education. As a result of a reform in 2002, they became independent bodies. The new accountability device central in this reform was labelled the 'Knowledge Balance Sheet' (KBS), which required from each of the universities to make arrangements with the ministry about their achievements in the areas of human assets, processes and outputs. The Habersam, Piber and Skoog paper investigates the way in which this accountability device was used by the various stakeholders, such as officials in the ministry and top level administrators and managers of the universities.

This paper presents some interesting observations which are in line with the more critical literature on governance and accountability. First, the KBS altered and refined the governance relationships in the university sector, especially by the inclusion of 'performance' on the agenda of the budget meetings between the universities and the ministry. Second, the benchmarking of performance had an impact on the budgeting process and also served as input for learning activities within the universities. Third, the performance information was assessed in terms of its relevance and reliability and often enriched by narrative information ('numbers and stories'), although the ministry remained to be focussed on the numbers. However, finally and most importantly, the public governance and accountability changed substantially, but not in the sense that uncertainty was abolished. On both sides of the budget game the participants' vulnerability in fact increased: the ministry became dependent upon the performance appointments and the universities still felt dependent upon the ministry as their main funder, which has tightened its control repertoire even more by further increasing its demand for accountability. 


\subsection{Performance measurement systems for accountability and internal control}

The ultimate goal of a governance system is to help achieve the organization's targeted performance. Therefore, performance measurement instruments have to provide internal stakeholders with information for internal control. In addition, they have to inform external stakeholders about the organization's achievements. The paper by Iris Saliterer and Sonja Korac deals with antecedents of performance information (PI) use with respect to internal control and accountability purposes in Austrian small and mid-sized local governments. These antecedents are defined at four different levels, the contextual, the inter-organizational, the intra-organizational and the individual level.

This paper makes at least three contributions to the body of knowledge on public sector performance measurement research. First, by studying the PI use in public sector organizations at both the political and the managerial levels, second, by examining whether the antecedents of PI use differ between internal control and accountability purposes, and third by investigating the impact of the various inter-organizational approaches on PI use, particularly internal autonomization, outsourcing and cooperation. A striking outcome of Saliterer and Korac's study is that politicians use PI more extensively than managers, which contradicts the findings of earlier studies. Moreover, this study indicates that a rational culture and management style are consistent antecedents of PI use, both for internal control and accountability purposes, and for politicians and managers. The inter-organizational antecedents of internal autonomization, outsourcing and cooperation, however, differ in their impact on PI use, while neither contextual antecedents (financial health and organizational size) nor the individual antecedent of a pro-NPM attitude have a significant influence on PI use. Future research needs to further examine the impact of inter-organizational regimes on PI use, not only because of the inconsistent findings of this study but also to address these complex issues in a more advanced way.

\subsection{Intelligent and value-laden accountability in a network context}

Linda English's paper presents some results of a prison reform in Western Australia, particularly the privatization of one of this state's prisons and its governance by the Department of Justice. The author describes the contractual arrangements with the private provider and discusses the kinds of control and oversight and their results. Generally, this case study shows an interesting picture of governance reform in a quite problematic environment (the prison as a closed institution). A core feature of the governance concept here has been the establishment of an independent regulatory body, the "inspector of custodial services". In describing and analyzing the structures and procedures of the performance evaluation of the prison services in Western Australia, English specifically emphasizes the privately operated prison. She qualifies the accountability regime, which is based on regular inspections and detailed performance measurement, as "intelligent accountability". The system considerably improved the prisons' performance but also resulted in a visible value shift as regards the relevant stakeholders. It differs from the rather traditional and hierarchical governance concept used by this government department, which is basically considered as quite weak but also regarded as slowly improving over time. However, the case study does illustrate the inability of this department to change its hierarchical governance, e.g. by devolving responsibilities to the local actors in the prisons. The research provides insights into the prerequisites for and elements of an intelligent accountability regime, e.g. a sophisticated surveillance concept and a highly transparent account of the results. Furthermore, English introduces various value concepts and demonstrates that the values of both prisons and government bodies have changed over time from a security orientation towards a more harmony-based values focused on care.

Generally, this paper provides valuable insights into the distribution of responsibilities and accountabilities in a networktype structure consisting of various public and private actors. Furthermore, it sheds light on the contractual relations between a governmental department and a private provider in the delicate context of custodial services. It shows the positive impact of an independent inspection regime on organizations' performance and accountability. Finally, the paper provides evidence for a successful private-oriented governance of prison organizations, with as basic criteria control and oversight.

\subsection{About the non-neutrality of accountability relationships}

Accountability is not a purely technical or neutral concept. It is generally influenced by two opposite ways of thinking on both sides of the accountability relationship, namely by the views of the accountor and the accountee. Jean Claude Mutiganda's paper contributes to our understanding of this non-neutral accountability relationship. It analyzes the impact of the institutionalization of governance and budgetary policies on the organizational actors' accountability from an institutional and critical realism perspective. By making use of critical realism the paper's aim is to extend the Burns and Scapens (2000) framework by investigating how institutionalized governance and budgetary policies affect the ways of thinking and the behaviour of the institutional actors in accountability relationships. The empirics are based on two field studies conducted in two hospital districts in Finland from 2009 to 2012. During the last two decades the Finish hospital sector has gone through NPM-like reforms with as basic elements the decentralization of the governing powers to the municipal level, competition among the hospitals, and the use of result-oriented management systems.

Mutiganda's study shows that the formal accountability relationship between the supervisory board (representing the municipal interests) and the hospital management, i.e. between the accountor and the accountee, is taken for granted by both parties. However, their institutionalized ways of thinking about accountability can substantially differ. Hospital managers argue that oversight body members are mainly interested in meeting the budgetary limits and realizing cost 
savings without having any real knowledge about how hospital care actually works. At the lower levels, the accountability relationships between the medical top managers and the medical professionals (doctors and nurses with managerial tasks) may differ. Efficiency-oriented ways of thinking among medical managers may result in a relational and instrumental form of budgetary accountability. However, if efficiency-oriented approaches used by top management are decoupled from the care-based views of medical managers, the accountability relationships may become primarily ceremonial.

\subsection{How internal auditors are coping with role conflicts in their work}

Accountability requires the assurance that financial and non-financial data used in reports about an organization's performance are trustworthy. Auditing procedures can contribute to this trustworthiness by assessing the validity and reliability of accounting reports. Often organizations have both external and internal auditors for these types of assessments. Internal auditors have the function of a watchdog vis-à-vis oversight bodies in general and auditing committees, which are part of these oversight bodies, in particular. The main contribution of the paper by Mélanie Roussy is that it challenges the watchdog role of the internal auditors in a public sector context. The study is based on interviews with experienced auditors in public sector organizations in the State of Quebec, Canada.

By using role theory to map out the various roles played by internal auditors, the paper shows that these actors are primarily the advisors and protectors of top management at the expense of their watchdog function on behalf of the auditing committees. Internal auditors try to cope with this tension between formal independency and a strongly felt loyalty towards the top management. Roussy introduces the term 'grey independency', which refers to the internal auditor who seeks to solve his/her role conflicts by trying to be independent but by forgiving him/herself for falling short of this independence in the strictest sense. Roussy warns against using simple solutions to failing to comply with the formal watchdog role, for example by re-emphasizing this function at the expense of the supporting role. With respect to finding solutions to issues of control, internal advice and auditing, she pleas for considering the whole governance mechanism, including the roles of the top management, the internal auditors, the controllers, the external auditors and the auditing committees.

\subsection{Financial and technical expertise of oversight body members}

A public sector organization needs people in management and control positions who have the right skills and sufficient experience. Governors may hold either executive or non-executive positions. When these positions are clearly separated, non-executives take part in an oversight body of the organization, which has a supervisory role towards (executive) top management. The paper by Ejia Vinnari and Salme Näsi examines the financial and technical competences of the members of the oversight body of the Finish water utilities.

This paper contributes in two ways to our knowledge of oversight body competences in the public sector. It firstly develops various measures for estimating financial and technical competence. Financial competence is, for example, estimated by assessing the background of oversight body members in terms of their education and experience in financial matters and by a self-evaluation of their financial expertise. The paper indicates that the financial competence of the oversight body members is generally quite low, although the self-perception of their financial expertise shows a positive bias. The second contribution of the paper is that Vinnari and Näsi try to explain the differences in the financial and technical competences of the oversight body members by using various theoretical lenses. They conclude that stewardship theory offers a good explanation for the fact that the oversight bodies of utilities with a relatively higher degree of autonomization with respect to the local government possess higher levels of financial and technical competences, while resource dependency theory indicates that the technical competences of members with a political affiliation are lower in comparison to those of outsiders. In a practical sense this paper raises questions as to whether oversight bodies need more outsiderprofessionals and whether the mechanisms for supervision and accountability, for example auditing procedures, are in fact sufficient for creating an adequate balance in terms of the political and professional values on which oversight bodies of public utilities should be based.

\section{Reflections on the papers and directions for future research}

This final section reflects on the papers presented in this special issue and suggests some directions for future research. Three general observations can be made with respect to the papers.

The first one is that in all but one of them, the overarching reform context is NPM. The exception is the paper by Linda English, who investigates accountability changes in a network of stakeholders in the sensitive context of custodial services. This observation implies that a great deal of research has still to be done on performance accountability in networks in which NPG is central, as set out in Section 2. In this respect it might be relevant to refer to the review paper by Provan and Milward (2001) on network performance. According to these authors, network performance is more complicated in the public sector than in the private sector because in the first the user needs of the constituent groups are relatively more diverse and politicized. Provan and Milward therefore propose a framework for analyzing public-sector network performance at three levels: the community, the network and the service provider.

The second observation is that, irrespective of the importance of NPM with its emphasis on private sector doctrines, in all of the papers the public sector context plays a pivotal role. The paper by Ejia Vinnari and Salme Näsi, for example, tries to 
explain the financial competences of oversight body members by investigating whether their backgrounds are political or non-political. The paper by Linda English about accountability in custodial services explicitly discusses the tensions between private and public sector values. And Jean Claude Mutiganda discusses two contrasting ways of thinking in the hospital sector, the one in support of NPM (stressing efficiency) and the other advocating public values, especially the concept of care. This observation implies that most papers critically discuss the elements of the private sector approach in a public sector context, which is core to what we, as public sector accounting researchers, are meant to do.

Third, we highly appreciate that most of the papers in this special issue have tried to combine a technical accounting focus with a critical analysis of the use of accounting instruments. In this respect, the paper by Michael Habersam, Martin Piber and Matti Skoog about changes in accountability as part of reforms in the Austrian university sector is a good example, but we also refer to other papers (particularly those by Linda English and Jean Claude Mutiganda).

In addition, we observed a tension between the particular focus on a relevant problem issue on the one hand and its role in the comprehensive governance context on the other hand. Mélanie Roussy's paper is a good example here. Her research critically and convincingly discusses the limited extent to which internal auditors can fulfil a watchdog role. However, because her research only addresses internal auditors as part of a much broader governance repertoire, this study does not come up with very concrete suggestions for coping with the role conflicts of internal auditors. In order to gain this understanding, the entire governance mechanism, consisting of top management, internal auditors, controllers, external auditors and auditing committees, would have to be considered. This broader governance domain has, however, not been the subject of study in the papers presented in this special issue. In brief, these observations suggest that more attention has to be paid to the relationships between the different elements of the public sector governance domain, which could be done by the realization of comprehensive research programmes in this field.

Finally, we would like to stress the need for more in-depth research on the impact of particular organizational forms, such as outsourcing and collaboration. Although these concepts have been addressed in the study by Iris Saliterer and Sonja Korac about performance measurement in Austrian municipalities, topics of this complexity should be operationalized in more advanced ways than done so far in the mainstream accounting studies based on cross-sectional survey data.

\section{References}

Ahrens T, Chapman CS. Accounting for flexibility and efficiency: a field study of management control systems in a restaurant Chain. Contemporary Accounting Research 2004;21(2):271-301.

Almqvist R. "Management by Contract" - a study of programmatic and technological aspects. Public Administration 2001;79(3):689-706.

Almqvist R. Icons of New Public Management - four studies on competition contracts and control. Stockholm: Stockholm University; 2004.

Almqvist R, Catasús B, Skoog M. Towards the next generation of public management: a study of management control and communication in the Swedish Armed Forces. International Journal of Public Sector Management 2011;24(2):122-45.

André R. Assessing the accountability of government-sponsored enterprises and quangos. Journal of Business Ethics 2010;97(2):271-89.

Antiroikko AV, Bailey SJ, Valkama P. Innovations in public governance in the western world. In: Antiroikko AV, Bailey SJ, Valkama P, editors. Innovations in public governance. Amsterdam: IOS Press; 2011.

Aucoin P. Administrative reform in public management: paradigms, principles, paradoxes, and pendulums. Governance $1990 ; 3(2): 115-37$.

Barberis P. The new public management and a new accountability. Public Administration 1998;76(3):451-70.

Barretta A. The functioning of co-opetition in the health-care sector: an explorative analysis. Scandinavian Journal of Management 2008;24(3):209-20.

Behn RD. Why measure performance? Different purposes require different measures Public Administration Review 2003;63(5):588-606.

Bevir M. Key concepts in governance. London: Sage; 2009.

Bovens M. Analysing and assessing accountability: a conceptual framework. European Law Journal 2007;13(4):447-68.

Bovens M. Public accountability. In: Ewan F, Lawrence Jr L, Pollitt C, editors. The Oxford handbook of public management. Oxford: Oxford Handbooks; 2009.

Broadbent J, Guthrie J. Public sector to public services: 20 years of 'contextual' accounting research. Accounting Auditing and Accountability Journal 2008;21(2):129-69.

Broadbent J, Dietrich M, Laughlin R. The development of principal-agent, contracting and accountability relationships in the public sector: conceptual and cultural problems. Critical Perspectives on Accounting 1996;7(3):259-84.

Bruijn, $\mathrm{H}$ de van Helden GJ. A plea for dialogue-driven performance-based management systems: evidence from the Dutch public sector. Financial Accountability and Management 2006;22(4):405-23.

Burns J, Scapens RW. Conceptualising management accounting change: an institutionalist framework. Management Accounting Research 2000;11(1):3-25.

Chan JL. Government accounting: an assessment of theory, purpose and standards. Public Money \& Management 2003;25(1):13-20.

Christensen T, Laegreid P. The whole-of-government approach to public sector reform. Public Administration Review 2007;67(6):1059-66.

Chow D, Humphrey C, Moll J. Developing whole of government accounting in the UK: grand claims, practical complexities and a suggested future research agenda. Financial Accountability and Management 2007;23(1):27-54.

Colley JL, Doyle JL, Logan GW, Stettinius W. What is corporate governance?. New York: McGraw-Hill; 2005.

Deleon L. Accountability in a "reinvented" government. Public Administration 1998;76(3):539-58.

Dubnick M. Accountability and the promise of performance: in search of the mechanisms. Public Performance and Management Review 2005;28(3):376-417.

Ferlie E, Ashburner L, Fitzgerald L, Pettigrew A. The new public management in action. Oxford: Oxford University Press; 1996.

Goddard A. Accounting and NPM in UK local government - contributions towards governance and accountability. Financial Accountability \& Management $2005 ; 21(2): 191-216$.

Gray A, Jenkins W. Codes of accountability in the new public sector. Accounting Auditing \& Accountability Journal 1993;6(3):52-67.

Greiling D, Spraul K. Accountability and the challenges of information disclosure. Public Administration Quarterly 2010;34(3):338-75.

Grossi G, Thomasson A. Jointly owned companies as instruments of local government: comparative evidence from the Swedish and Italian water sectors. Policy Studies 2011;32(3):277-89.

Grossi G, Newberry S. Special issue theme of whole of government financial reporting: international trends. Public Money \& Management 2009;29(4):209-18. Guthrie J. Application of accrual accounting in the Australian Public Sector: rhetoric or reality? Financial Accountability and Management 1998;14(1):3-19.

Helden, G J van, Johnsen A, Vakkuri J. The lifecycle approach to performance management: implications for management and evaluation. Evaluation 2012;20(4):18-38.

Hodges R. Joined-up government and the challenge to accounting and accountability researchers. Financial Accountability and Management 2012;28(1):26-51.

Hoffman WH, Neumann K, Speckbacher G. The effect of interorganizational trust on make-or-cooperate decisions: disentangling opportunism-dependent and opportunism-independent effects of trust. European Management Review 2010;7(2):101-15. 
Hood C. The "new public management" in the 1980s: variations on a theme. Accounting Organisations and Society 1995;20(2/3):93-109.

Humphrey C, Miller P, Scapens RW. Accountability and accountable management in the UK public sector. Accounting Auditing and Accountability Journal 1993;6(3):7-29.

Klijn EH. New public management and governance: a comparison. In: Levi-Faur D, editor. Oxford handbook of governance. Oxford: Oxford University Press; 2012 Kooiman J. Governing as governance. London: Sage; 2003.

Koppenjan JFM, Klijn EH. Managing uncertainties in networks: a network approach to problem solving and decision making. London: Routledge; 2004.

Kurunmäki L, Miller P. Regulatory hybrids: partnerships, budgeting and modernising government. Management Accounting Research 2011;22(4):220-41.

Lapsley I. Accounting and the new public management: instruments of substantive efficiency or a rationalising modernity? Financial Accountability and Management 1999;15(3/4):201-7.

Lapsley I. New public management: the cruellest invention of the human spirit? Abacus 2009;45(1):1-21.

LeGrand J. Competition, cooperation, or control? Tales from the British National Health Service Health Affairs 1999;18(3):27-39.

Lüder K, Jones R, editors. Reforming governmental accounting and budgeting in Europe. Fachverlag Moderne Wirtschaft: Frankfurt am Main; 2003.

Mulgan R. Comparing accountability in the public and private sectors. Australian Journal of Public Administration 2000;59(1):87-97.

Olson O, Humphrey C, Guthrie J. International experiences with “new” Public Financial Management (NPFM) reforms: new world? Small world? Better world?"In: Olson O, Humphrey C, Guthrie J, editors. Global warning: debating international developments in new public financial management. Oslo: Capelen Akademisk Forlag As; 1998.

OECD. Principles of corporate governance. Paris: OECD; 2004.

Osborne SP. The new public governance? Public Management Review 2006;8(3):377-87.

Osborne SP. The introduction. The (New) Public Governance: a suitable case for treatment?In: Osborne SP, editor. The New Public Governance? Emerging perspectives on the theory and practice of public governance. London: Routledge; 2010.

Polidano C. Why bureaucrats can't always do what ministers want: multiple accountabilities in Westminister democracies. Public Policy and Administration $1998 ; 13(1): 35-50$.

Pollitt C, Bouckaert G. Public Management Reform: a comparative analysis, new public management, governance, and the neo-weberian state. 3rd ed. Oxford: Oxford University Press; 2011.

Power M. The audit society: rituals of verification. Oxford: Oxford University Press; 1997

Power M, Laughlin R. Critical theory accounting. In: Alveson M, Willmott H, editors. Critical management studies. London: Sage; 1992.

Provan KG, Milward HB. Do networks really work? A framework for evaluating public-sector organizational networks Public Administration Review $2001 ; 61(4): 414-23$.

Reichard C. New public management. In: Anheier HK, Toepler St., editors. International encyclopedia of civil society. Berlin: Springer; 2010.

Rhodes RA. Understanding governance. Policy networks, governance, reflexivity and accountability. Maidenhead: Open University Press; 1997.

Roberts J, Scapens R. Accounting systems and systems of accountability - understanding accounting practices in their organisational contexts". Accounting Organizations and Society 1985;10(4):443-56.

Romzek BS. Dynamics of public sector accountability in an era of reforms. International Review of Administrative Sciences 2000;66(21):21-44.

The Independent Commission on Good Governance in the Public Sector, The Good Governance Standard for Public Services. London: OPM and CIPFA; 2004.

Romzek BS, Dubnick MJ. Accountability in the public sector: lessons from the challenger tragedy. Public Administration Review 1987;47(3):227-38.

Shaoul J, Stafford A, Stapleton P. Accountability and corporate governance of public private partnerships. Critical Perspectives on Accounting 2012;23(3):213-29.

Sinclair A. The chameleon of accountability: forms and discourses. Accounting Organizations and Society 1995;20(2/3):219-37.

Smyth S. Contesting public accountability: a dialogical exploration of accountability and social housing. Critical Perspectives on Accounting 2012;23(3):230-43.

Walsh K. Public services and market mechanisms - competition contracting and the new public management. Houndmills: MacMillan; 1995.

Walsh K, Deakin N, Smith P, Spurgeon P, Thomas N. Contracting for change. In: Health social care and other local government services. Oxford: Oxford University Press Inc.; 1997.

Watkins AL, Arrington CE. Accounting new public management and American politics: theoretical insights into the national performance review. Critical Perspectives on Accounting 2007;18(1):33-58.

Watt PA. White-collar services in local government: competition and trust. In: Coulson A, editor. Trust and contracts - relationships in local government, health and public services. Bristol: The Policy Press, University of Bristol; 1998.

Wouters M. A developmental approach to performance measures: results form a longitudinal case study. European Management Journal 2009;27(1):64-78.

Roland Almquist

Stockholm University, Sweden

Giuseppe Grossi*

Kristianstad University, Sweden

G. Jan van Helden

Groningen University, The Netherlands

Christoph Reichard

Potsdam University, Germany

*Corresponding author.

E-mail address: giuseppe.grossi@hkr.se (G. Grossi) 